Irina Purcarea*

\title{
The Place of Small and Medium Enterprises within the Sustainable Development Framework
}

\section{Summary}

Small enterprises make up for at least 95\% of the enterprises in the European Community, and constitute an important source of employment. Sustainable development, on the other hand, involves each of us, individual or organization. It is a concept that should be embraced by each of us, by each enterprise no matter its size. Each company should clearly understand the concept and undertake the specific actions considering the fact that their impact will have certain effects that will echo in the future, therefore affecting future generations. The present research intends to gain an insight into the approach adopted by small and medium enterprises as concerning the sustainable development framework, with a focus on corporate social responsibility initiatives undertaken by SMEs.

\section{Introduction}

Small and medium enterprises play an extremely important role in creating a dynamic economy, boosting economic growth and therefore special attention should be given to providing a proper development framework for SMEs. Small firms make up for at least 95\% of enterprises in the European Community and the contribution these firms make to the economies of their countries is to be acknowledged.

Moreover, promoting entrepreneurship through the setting-up of small and medium enterprises is very important if we are to consider the transition to the market economy and the democratization of the society. Small and medium enterprises can be considered a source of sustainable development and the connection between small and medium

\footnotetext{
* Academy of Economic Studies, Bucharest, Romania.
} 
enterprises should be thoroughly analyzed if we are to consider a long-term development framework.

Sustainable development refers to managing the use of resources so that present needs are met without making it hard for future needs to be met as well. Economic Sustainability emphasizes the role of information as well as the need to develop new approaches while integrating environmental and social concerns into all development processes.

\section{Small and medium enterprises and the dynamic competitiveness}

A key role in achieving the Lisbon objective of the European Union, namely to become, until 2010, the most competitive and dynamic economy in the world, was attributed to small and medium enterprises (SMEs). At the beginning of 2004, the "Report"1 which evaluated, within the Lisbon European Council, the progress made in the economic reform in March 2000 was put forward, inviting to further progress in the years that follow. It shows that: "A dynamic and productive economy requires an economic environment that can sustain the key productivity factors - competition, enterprises, investments, innovation and abilities...In order to effectively compete in an integrated and competitive global economy, Europe must improve its capacity to innovate and develop an entrepreneurial culture.

Most importantly, a lot of attention should be given to analyzing the main drivers of competitiveness. If we are to look at the renewed Lisbon strategy, raising the long-term economic growth potential through increasing productivity growth represents one of the fundamental objectives that were taken into account.

Increased investment in R\&D in case of small and medium enterprises is highly encouraged as it can lead to an increase in productivity growth, together with appropriate organizational changes and investments in skills through education and training.

Increasing the speed of innovation remains a challenge for small and medium enterprises. The process of innovation is closely linked to increasing the dynamic competitiveness of small and medium enterprises by expressing the combination between the markets 'knowledge, technology, creativity and the process of gathering knowledge with the purpose of solving problems regarding the competition.

Another important aspect is the necessity for easing the process of setting-up the company and the growth stage, in other words, stimulating entrepreneurship also by allowing new ideas to be transformed into value added products and services. In this regard, orienting small and medium enterprises towards the knowledge management can play a significant role in sustaining creativity and generating new ideas.

Due to the European integration, the competition has increased both on the international and national markets and the quality and the services offered to the customer are considered to be major factors of competitiveness for small and medium enterprises. High-tech small and medium enterprises contribute to increasing the life standard,

${ }^{1}$ HM Treasury's „Advancing long-term prosperity: Economic reform in an enlarged Europe”, Crown, February 2004, pg. 6, 8, 45-46, 49, 65, 87-88. 
productivity and competitiveness by creating and implementing technological innovation, also possessing an important potential for contributing to employment and increasing revenues. Further attention should be given to this category of SMEs, especially in Europe, as they remain behind those in the United States.

\section{Viewing sustainable development from the perspective of small and medium enterprises}

Sustainable development implies a better quality of life at present as well as what concerns the future generations. It is important to acknowledge the fact that it is required to set immediate and long-term objectives, implement local and global actions, consider both economic and environmental issues, viewing all these elements in an interdependent manner so as to have a complete view upon the society. Such a view must be strengthened by encouraging certain principles to be followed, such as political, economic, social principles.

The European Union has developed a Strategy for Sustainable Development, which emphasizes the following objectives:

- climate change and clean energy,

- sustainable transport,

- sustainable consumption and production,

- conservation and the management of natural resources,

- public health,

- social inclusion, demography and migration,

- global poverty.

Improving the quality of life is strongly connected with managing resources in a sustainable manner by imposing proper public policies at an internal level, as well as promoting cooperation at international level, in order to elaborate comprehensive strategies that are meant to provide concrete results.

Nowadays, small and medium enterprises are encouraged to integrate environmental and social concerns into their processes and into their way of 'doing business'. The concept of corporate social responsibility is meant to prepare each enterprise to create sustainable development which implies advantages for both the organization and its stakeholders.

In what concerns small and medium enterprises, there seems to be a lack of understanding of this concept as well as relating the concept to larger firms, multinationals who, in their opinion, seem to be more entitled to develop and implement CSR practices within their companies. Therefore, it is important to develop such a way of thinking as to raise the awareness concerning the link between social and environmental issues sustainable success, these issues constituting factors of sustainable success. Also, a link between activities based on a stakeholder approach and the enterprise's competitiveness should be emphasized.

Most importantly, small and medium enterprises do not always acknowledge that the activities they perform are related CSR area. There is the classification by the "target group" of CSR activities, and the following CSR fields can be illustrated: 
Graph 1. Target groups for SMEs' CSR activities

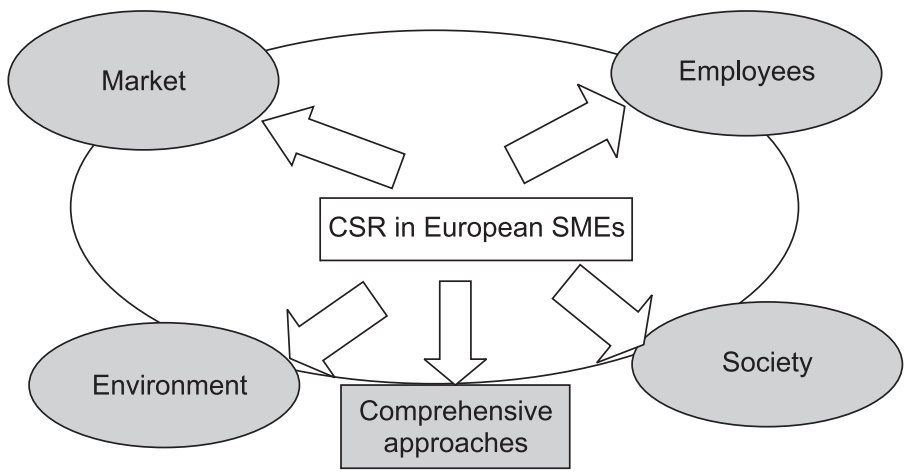

Source: Austrian Institute for SME Research

1. Market: it includes business activities related to responsible supply chain management, improving the quality ors of products, innovation or ethical advertising.

2. Employees: CSR activities such as improvement of working conditions, pay and benefits or job creation, training and staff development. CSR initiatives may also refer to informing employees as well as allowing them to participate in the decision making process.

3. Society: social integration, education, healthcare, quality of life, security.

4. Environment: CSR activities focusing on an efficient use of resources and the reduction of waste and pollution by using environmental management systems, eco design tools, eco labels or cleaner production techniques.

The CSR initiatives of small and medium enterprises usually aim at the employees as the main 'target' group, therefore the internal environment, activities such as guaranteeing sustainable development, career planning and developing human resources, improving working conditions as well as involving employees in the decision-making process.

\section{Conclusions}

A sustainable economy implies accepting and dealing with new challenges and opportunities. In order to build a powerful economy, the European Union intends to strengthen the entrepreneurial spirit in Europe and create the necessary conditions to develop innovative practices in small and medium enterprises in order to become more competitive. It should be acknowledged the fact that orienting small and medium enterprises towards sustainable practices can build a competitive advantage for SMEs on the long-term. Small and medium enterprises should adopt a strategic approach to sustainable development, by integrating environmental and social concerns into their 
operations, by focusing more on CSR practices and developing CSR programs that aim not only at the employees, as the sole 'target' group, but also on the society as a whole. Looking at the economies of the countries from Central and Eastern Europe, the speed and importance of privatization and reorganization of public enterprises is strongly connected with the creation and development of SMEs. This sector needs enterprises that should focus on a "visionary" management which develops an orientation that takes into account the present - future axis, therefore integrating the sustainable development issue, by implementing CSR programs meant to contribute to the development of a sustainable economy.

\section{References}

Burns P., Corporate Entrepreneurship: building an entrepreneurial organization, Palgrave Macmillan, Houndmills, Basingstoke, Hampshire 2005.

Commission of the European Communities, Communication from the Commission - Raising productivity growth: key messages from the European Competitiveness Report 2007, Brussels, 31.10.2007.

HM Treasury's, Advancing long-term prosperity: Economic reform in an enlarged Europe, Crown, February 2004.

Mandle I., Dorr N, CSR and Competitiveness- European SMEs Good Practice (consolidated European report), Austrian Institute for SME Research, Vienna 2007.

http://ec.europa.eu/sustainable/welcome/index_en.htm

\section{Rola małych i średnich przedsiębiorstw w systemie rozwoju zrównoważonego}

\section{Streszczenie}

Sektor matych i średnich przedsiębiorstw (MSP) obejmuje przynajmniej 95\% wszystkich podmiotów gospodarczych w Unii Europejskiej. Rozwój zrównoważony interesuje każda organizację gospodarcza, bez względu na jej wielkość. Ważne jest poznanie istoty tego rozwoju oraz czynników go kształtujacych. W artykule prezentowane sa głównie rozważania nad odpowiedzialnościq społeczna MSP w systemie rozwoju zrównoważonego. 